Savunma Bilimleri Dergisi

The Journal of Defense Sciences

Kasım/Nov 2017, Cilt/Volume 16, Say1/Issue 2.

ISSN (Bas111) : 1303-6831 ISSN (Online): 2148-1776

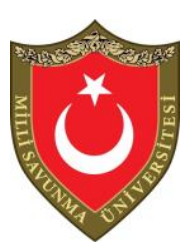

\title{
Küresel Güvenliğin Dönüşümü; NATO Bağlamında Kavramsal, Tarihsel ve Teorik Bir Analiz ${ }^{1}$
}

\author{
Güngör ŞAHINN ${ }^{2}$
}

$\ddot{O} z$

Kuzey Atlantik Antlaşması Örgütü (NATO) realist kurama uygun bir şekilde, gerektiğinde güç kullanmak suretiyle Batı Bloğunun güvenliğini sağlamak amacılla kurulmuştur. Ancak Soğuk Savaş sonrası dönemde, Doğu Bloğu tehdidinin ortadan kalkmasına ve nükleer silahların sınırlandırılması konusundaki girişimlerin olumlu sonuçlanmasına rağmen, NATO'nun mevcudiyetini yitirmediği gözlemlenmiştir. Örgüt, neo-liberal kuram doğrultusunda, üye devletlerin güvenlik iş birliğini kolaylaştırdiğı ve insani müdahalede bulunma kapasitesine sahip olduğu gerekçesiyle varlı̆̆ını sürdürmeye, 1990 sonrası dönemde sorumluluk sahasını da genişleterek "alan dışı" görev ve yetkilerle hegemonyasını arttırmaya devam etmiştir. Ayrıca 11 Eylül 2001 terör saldırlarından sonra, neoliberal kuram yanında sosyal inşacı kuramın; teröre destek veren ülkelere karşı "biz" hissi yaratarak işbirliğini kolaylaştırdı̆̆ tezi, varlığının temel dayanaklarından biri olmuştur. Çalışma, küresel güvenlik sistemi içindeki değişimin unsurlarını tespit etmek, eski ve yeni dönem arasındaki bağlantıyı kurabilmek ve değişen/dönüşen güvenlik anlayışında; realist, neo-liberal ve sosyal inşacı kuramlar ışı̆̆ında, Soğuk Savaş sonrası dönemdeki zirveleri ve müdahaleleri çerçevesinde NATO'nun dönüşümünü değerlendirmektedir.

Anahtar Kelimeler: Soğuk Savaş, Tehdit, Güvenlik, NATO, Kuram.

${ }^{1}$ Güngör Şahin, Soğuk Savaş Sonrası Değişen Güvenlik Anlayışı Bağlamında NATO, Trakya Üniversitesi Sosyal Bilimler Enstitüsü, Edirne, 2015, adlı doktora tezinden türetilmiștir.

${ }^{2}$ Dr.Per.Alb., Milli Savunma Üniversitesi, Atatürk Stratejik Araştırmalar Enstitüsü (ATASAREN), Uluslararası İlișkiler ve Bölgesel Çalıșmalar Anabilim Dalı Öğretim Görevlisi, e-posta: gsahin@msu.edu.tr 


\title{
The Transformation of Global Security; A Conceptual, Historical and Theoretical Analysis in the Context of NATO
}

\begin{abstract}
In accordance with the international relations theory of realism, The North Atlantic Treaty Organization (NATO) was established in order to provide security for the Western Bloc by using force if necessary. However, despite the success in the attempts to limit nuclear weapons and the cessation of the Eastern Bloc threat, it was seen that NATO did not cease to exist. Due to the neo-liberal policies, NATO continued its existence with the justification that it was capable of making humanitarian interventions and facilitating the security cooperation of the member states. NATO expanded its area of responsibility starting from 1990's by trying to augment its hegemony by out-of-area operations and authorizations with the justification that it facilitated security cooperation and moved with the principle of humanitarian responsibility in accordance with neo-liberalism. This effort was also observed in NATO summits. After 9/11 terrorist attacks, along with neo-liberalism, the social constructivism's hypothesis which defends that by creating a spirit of union against terrorism, NATO facilitates cooperation has been one of the founding values of NATO. This study tries to determine the elements of change in the global security system make connections between the old and new eras and evaluate the NATO's transformation within the framework of its Post-Cold War summits and interventions, while considering the changing understanding of security, realist, neo-liberalist and social constructivist theories.
\end{abstract}

Keywords: Cold War, Threat, Security, NATO, Theory.

\section{Giriş}

Uluslararası ilişkilerde yirminci yüzyıl, mevcut tüm dengeleri değiştirmiştir. Bu yüzyıldaki iki büyük dünya savaşı ve sonrasında yaşanan Soğuk Savaş, devletlerin bekası için güvenlik olgusunu daha önemli hale getirmiştir. Doğu-Batı rekabeti, nükleer mücadele ve buna bağlı gelişen dehşet dengesi; devletleri ve halkları, her an üçüncü bir dünya savaşının çıkması endişesiyle baş başa bırakmıştır (Griffiths vd., 2013: 174). Söz konusu yıllarda, güvenliğin her zamankinden daha maliyetli ve elde edilmesinin daha güç olduğu görülmüştür. Öyle ki her iki kutupta da devletler, önderlerini izleyerek kolektif savunma örgütlerine dâhil 
Küresel Güvenliğin Dönüşümü; NATO Bağlamında Kavramsal, Tarihsel ve Teorik Bir Analiz

olmuşlardır. Bir tarafta Batı Bloğu üyelerinin güvenliğinin teminatı Kuzey Atlantik Antlaşması Örgütü (NATO), diğer tarafta rakibi Varşova Paktı (WP), güvenlik siyasetinin yeni aktörleri olarak uluslararası sistemde kendilerine yer bulmuşlardır.

Soğuk Savaş'ın sona ermesiyle birlikte çözülmeye başlayan Doğu Bloğu ve kendisine bağlı siyasal, ekonomik ve askeri erkin uluslararası sistemde etkisizleşmesi, NATO'nun da geleceği konusundaki belirsizlikleri beraberinde getirmiştir. WP'nin kendisini feshetmesiyle birlikte ortada bir rekabet kalmadığından, artık NATO’ya gerek bulunmadığını iddia edenler ortaya çıkmıştır (Medcalf, 2005: 3). Bu iddia karşısında, başta İngiltere olmak üzere NATO’nun varlığının Batı'nın geleceği için hayati önem taşıdığını öne süren ülkeler ve neo-liberal görüșler, örgütün mevcudiyetini yitirmemesi adına çaba göstermişlerdir. Nihayetinde neo-liberal kuram dâhilinde NATO; devletlerin ve uluslararası örgütlerin güvenlik ve diğer konu başlıklarında işbirliğini kolaylaştırdığı, insani sorumluluk prensibiyle krizlere ve çatışmalara müdahale ettiği gerekçesiyle meşruiyetini devam ettirmiş ve böylece kendisini alan dışına da taşıyıp adeta "dünya polisi" statüsü kazanmıştır.

Kabul edilmelidir ki, insan yaşamının ilk anından itibaren süregelen güvenlik ihtiyacı, dönem dönem değişim-dönüşüm yaşamamış ve bu süreç halen devam etmektedir. Çalışma; "devlet merkezli askeri güç ile özdeşleşen realist güvenlik anlayışının değiştiği, güvenlik siyasetinin öznelerinin çeşitlendiği, tehdit ve risklerin arttığı, ulus-devletlerin yanında uluslararası örgütler ve diğer aktörlerin de faal olduğu bu yeni dönemde, NATO'nun güvenlik ve işbirliğini kolaylaştırdığı düşünülen neo-liberal kurama ek olarak, sosyal inşacılık kuramı çerçevesinde "biz" kimliği yarattığ 1 için mevcudiyetini korumaktadır" tezini savunmaktadır. Tez ortaya koyulurken; kavramsal, kuramsal ve tarihsel olarak güvenliğin dönüşümü incelenmiş, bu bağlamda büyük ölçüde NATO zirvelerinden ve müdahalelerinden yararlanılmıştır. Çalışma, küresel güvenlik siyaseti içindeki değişimin unsurlarını tespit etmek, eski ve yeni dönem arasındaki bağlantıyı kurabilmek ve değişen/dönüşen güvenlik anlayışında NATO'nun meşruiyetini sorgulayabilmek adına önem arz etmektedir.

\section{Kavramsal ve Teorik Çerçeve}

\section{Kavramsal Çerçeve}

Uluslararası ilişkiler disiplininde hatırı sayılır bir yere sahip olan Arnold Wolfers'ın, bugünkü anlamıyla ilk defa bahsettiği güvenlik kavramı; 
"edinilmiş değerleri tehlikeye atan veya atma ihtimali bulunan herhangi bir tehdidin olmaması olduğuna göre", mevzubahis kavrama ilk insandan bu yana yaşamsal önem atfedilmektedir (Wolfers, 1952: 484-485). Öyle ki küreselleşen dünyada güvenlik kavramı, uluslararası ilişkiler alanında sistemin yapısını belirleyip anlayabilmede önemli bir rol oynamaktadır. Farklı uluslararası ilişkiler okullarının arasındaki pek çok karşıtlığı da ortaya koyan güvenlik kavramı, ulus-devletler arasındaki ilişkileri düzenleyen temel belirleyici olma özelliğini sürdürmektedir (İzci, 1998: 403-404).

Çok boyutlu bir araştırma alanına dönüşen güvenlik kavramının açıklanmasında; askeri unsurların yanına iktisadi, politik, toplumsal, psikolojik boyutlar dâhil olmuş ve çalışmalar gün geçtikçe artıp derinleşmiştir. Brauch'un deyişiyle güvenlik, sosyal bilimler çerçevesinde yapılan çalışmalarda belli başlı tanımlamalara karşılık gelen, kişilere, olgulara, kurumlara, toplumsal ritüeller ile duruma göre farklılaşan koşullara ve olaylara göre açıklanabilen önemli bir konu olmaktadır (Brauch, 2012: 168). Ancak sosyal bilimlerin temel sorunsalı olan "ortak bir tanımda buluşamamak", güvenlik kavramı için de geçerlilik arz etmektedir (Hobsbawm, 2006: 19). 1940'lara kadar strateji kavramıla eş değerde kullanılan güvenlik kavramı, daha sonraki on yıllarda çeşitli okulların ve buna bağlı fikirler üreten bilim insanlarının katkılarıyla bağımsızlaşarak güçlenmeye başlamıştır. Güvenlik yaklaşımlarında öne çıkan üç ana yaklaşım olarak realist güvenlik yaklaşımı, Kopenhag Okulu ve eleştirel güvenlik yaklaşımını göstermek doğru olacaktır.

Realist güvenlik yaklaşımına göre, düzeni garanti altına alacak bir otoriteden mahrum olan anarşik uluslararası sistemde, hiçbir devlet kendini tamamen güvende hissetmediği için rekabet devam etmekte ve sonuç olarak devletler arasında giderek büyüyen güvensizlik sarmalı, "güvenlik ikilemi" ortaya çıkmaktadır (Griffiths vd., 2013: 135). Bu "güvenlik ikileminin" devletlerin tek başlarına yapacakları girişimlerle değil, NATO ve WP gibi devletlerarası ortak kurumlar kurarak aşılabilmesi "kollektif güvenlik" düşüncesi ile mümkün olmuştur. Güvenliğin söylemsel olarak inşa edilen bir kavram olduğu, ilk olarak Kopenhag Okulu tarafından gündeme getirilmiş ve güvenliğin ulus-devletin savunma anlayışının ötesinde çok boyutlu hale gelmesi, "güvenlikleştirme" savı çerçevesinde kavramsallaştırılmıştır. Kopenhag Okulu bünyesinde Barry Buzan ve Ole Waever'ın çalışmaları ön plana çıkmaktadır. Güvenliğin sadece askeri güvenliğe indirgenemeyeceğini, yeni güvenlik alanlarına genişlemesinin daha uygun olacağını ileri süren Kopenhag Okulu, bu çerçevede beş güvenlik alanı sıralamaktadır: askeri, siyasal, ekonomik, çevresel ve toplumsal güvenlik (Brauch, 2008: 7). Benzer şekilde Kopenhag Okulunun 
bir diğer düşünürü Ole Waever da toplumsal güvenlik kavramını kullanarak devlet güvenliğinin dişında bir güvenlik tanımlamasına ihtiyaç duyulduğunu belirtmiştir (Weaver, 2008: 153). Waever ayrıca, güvenliği; "şifahi eylem" olarak da tanımlamaktadır (Kelstrup, 2004: 111). Buna göre, telaffuz etmekle birlikte güvenlik eyleminin kendisi meydana gelmektedir (Karyotis, 2007: 274). Bu açıdan bakıldığında risk olarak addedilen kimi durumlar, yetkililer tarafindan güvenlik sorunu olarak telaffuz edilmesiyle normal birer sorun ya da senaryo olmaktan çıkarak tehdit seviyesine yükselmekte ve ciddi bir güvenlik problemi olarak düşünülmektedir (Bilgin, 2003: 200). Barry Buzan ve Lene Hansen tarafından yapılan bir çalışmada 11 farklı güvenlik yaklaşımına değinilmektedir (Buzan ve Hansen, 2009: 35). Eleştirel güvenlik yaklaşımları içinde Galler Okulu (Aberyswyth Okulu) özgün bir konuma sahip bulunmaktadır. Galler okulu, İngiltere Aberyswyth Üniversitesi'nde Ken Booth, Richard Wyn Jones, Andrew Linklater, Keith Krause ve Michael Williams gibi akademisyenler tarafından gerçekleştirilen eleştirel güvenlik çalışmalarıyla tanınmaya başlanmıştır (Birdişli, 2014: 72). $\mathrm{Bu}$ okulun merkezinde, insan odaklılık bulunmaktadır. İnsana yönelik her türlü tehdidin güvenlik sorunu oluşturabileceğini söyleyen yaklaşıma göre güvenlik sorunun bertaraf edilmesinin tek çözümü "özgürleştirme", yani insanı zincirleyen o zincirlerinden kurtulmasını sağlayacak her türlü yaklaşımın güvenlik bunalımını çözebileceğini iddia etmektedir (Şahin, 2016: 279-287).

\section{Teorik Çerçeve}

Uluslararası ilişkiler kuramları, genel itibariyle uluslararası ilişkilerin tanımı, yapıs1, öznesi, meseleleri ve araştırma gündemi konusunda farklı fikirleri ortaya koymaktadır. Her kuram, öncelikle, kendine özgü bir uluslararası ilişkiler "gerçekliği”" tanımlamaktadır (Ağcan, 2014: 79).

\section{Realist Güvenlik Yaklaşımı}

Realist paradigma, 1940'lardan 1980'lere kadar uluslararası ilișkiler disiplinin başat kuramı olarak görülmüştür. Zaman içerisinde pek çok açıdan eleştiriye uğramış ve sorgulanmışsa da, yapılan eklemeler ve kuramın geçirdiği gelişme aşamaları ile bugüne dek varlığını sürdürmüş, uluslararası ilişkileri incelemek ve açıklamak için kullanılmaya devam etmiştir (Aydın, 2004: 34). Bu akımın en önemli temsilcisi Hans J.Morgenthau olarak gösterilmektedir (Gönlübol, 2000: 5). Realizm akımının uluslararası politika yazınındaki yerini iyice belirginleştiren 
Edward Hallet Carr olmuştur (Sönmezoğlu, 2009: 14-15). Realist kuramın temel varsayımlarını güç, çıkar ve insan doğası üzerine dayandırmaktadır (Bozdağlıoğlu, 2007a: 139). Amerikalı akademisyen Kenneth N.Waltz, 1979 yilında yayınlanan Theory of International Politics adlı eseriyle realizme karşı azalan ilgiyi yeniden canlandırmıştır. Kendisi de realist olmakla beraber, kitabında yer verdiği; "Devletlerin uluslararası sistemdeki konumlarını ve davranışlarını büyük ölçüde sistemin görünmez yapısı belirlemektedir." ifadesiyle neo-realist kuramı yaratmıştır (Waltz, 1959: 8790). Waltz'ın bakışıyla, ülkeler uluslararası ilişkilerin yapısı dâhilinde iş birliğini tesis edebildikleri takdirde, ellerindeki olanakları azamileştirerek topyekûn bir gelişme ve bütün medeniyetler adına bir ilerleme sağlayabileceklerini bilmelerine rağmen, uluslararası ilişkilerin anarşik çerçevesi çoğu kez güvenlik konularını ve korkularını ileri sürmekte, ülkeleri ortaklıktan ve uluslararası paylaşımdan uzaklaştırmaktadır (Aydın, 2004: 48). Realist kuramdan beslenen gücü ve çıkarı artırma isteği, uluslararası sistemin anarşik yapısından kaynaklanan güvenlik endişesinin giderilmesi için bu kuramın önermelerinden olan devletlerarası işbirliği ve ittifaklar sistemi, İkinci Dünya Savaşı sonrasının politik ve askeri ortamına damgasını vurmuştur. NATO'nun kollektif güvenlik örgütü olarak kurularak Batı Almanya'nın 1955 yılında NATO'ya üye yapılması, bu durumu kendisine karşı bir tehdit olarak algılayan Sovyet Sosyalist Cumhuriyetler Birliği (SSCB) tarafından aynı yıl karşı kollektif güvenlik örgütü olarak WP'nın kurulması, bu bağlamda değerlendirilebilir. $\mathrm{Bu}$ düşünceden hareketle kurulan NATO Soğuk Savaş döneminde konseptini; Doğu-Batı ve nükleer rekabetin de etkisiyle realist kuramın gerektirdiği şekilde güç üzerine şekillendirmiş, her an çıkabilecek bir savaşa hazır olmuştur.

\section{Liberal Güvenlik Yaklaşımı}

Liberal yaklaşımlar, realistlerden ayrı biçimde "çatışma yerine barış ve iş birliği”" temaları üstünde yoğunlaşmaktadır (Arı, 2006: 368-369). Liberal kuram, uluslararası ilişkiler analiz düzeyinde çoğulcu bir yaklaşım içselleştirilerek; birey, sivil toplum kuruluşları, ulus-devlet, uluslararası örgütler ve uluslaraşırı gruplar seviyesinde icra etmektedir. Moravcsik, bireyleri ve ulusal baskı gruplarını da uluslararası arenada önemli aktörler olarak görmekte, yüksek politika alanlarında iş birliğini olanaklı kabul etmektedir (Moravcsik, 1993: 475-477). Robert O.Keohane ve Joseph S.Nye, realizme karşı "karmaşık karşılıklı bağımlılık" (Complex Mutual Interdependence) modelini ortaya atmaktadırlar. Keohane ve Nye'a göre, İkinci Dünya Savaşı sonrası dönemde ülkeler arasında artan ticari, kültürel 
ve politik ilişkiler askeri gücün kullanılmasının sınırlanmasına yol açmıştır. Devletlerin süregelen önemini kabul ettikleri hâlde, uluslararası gündemin gittikçe artan bir şekilde uluslararası ve uluslarötesi aktörler tarafindan oluşturulduğunu iddia etmektedirler (Keohane ve Nye, 2007: 349-352). Keohane ve Nye'a göre günümüzde hükümet dışı aktörler faaliyetlerini hızlandırmış ve çok uluslu şirketler ise kurumsallaşarak daha rekabetçi olmaya başlamıştır (Keohane ve Nye, 2000: 114). Soğuk Savaş döneminin sona ermesi ve küreselleşmenin etkisi, devletler ve çok uluslu şirketler arasında ekonomik ilişkileri artırarak silahlı çatışma ihtimalini azaltmıştır. Küresel güçler arasında büyük yıkıma ve tahribata sebebiyet verebilecek savaş olasılığının geçici de olsa ortadan kalktığı rahatlıkla söylenebilir. Buna karşılık bölgesel, etnik ve dinsel içerikli savaş veya çatışmalar hâlihazırda önemini muhafaza etmektedir. Asimetrik bir tehdit olarak bu dönemde terörizm kendisini yakından hissettirmiş ve küresel bir boyut kazanmıştır. WP ve SSCB'nin dağılmasıyla birlikte ulus-devlet güvenlik anlayışı; yeni tehdit ve risklerin (terörizm, uluslararası göç, enerji, çevre gibi) ortaya çıkmasıyla küresel güvenlik şeklinde ifade edilen bölgesel ve uluslararası güvenlik anlayışına doğru evirilmiştir. Bu bağlamda güvenlik olgusunun içeriği de genişlemiş, yeni tehdit ve risklerle mücadele için kurumsal hafızası yüksek olan NATO'nun devamını isteyenler, üye devletler arası işbirliğini kolaylaştırdığını ileri süren neo-liberal kuramcıların fikirlerini öne sürmüşlerdir. $\mathrm{Bu}$ dönemde realist kuramın yerine neo-liberal kuramın etkisiyle askeri boyuta haiz sert güvenlik tedbirleri yerine daha yumuşak güvenlik tedbirleri alınmasına özen gösterilmiştir. NATO'nun konseptinde üyeler arası işbirliğini ve yeni devletlerle ortaklıkları öngören, temelde barışı hedefleyen daha küresel politikalar üretilmeye başlanmış, zirvelerde bu barış ve işbirliği ortamının önemi vurgulanmıştır. Müdahaleler, kriz yönetimi ve barışı destekleme operasyonlarına bakıldığında "insani ilkeler" ön planda tutulmuş ve neoliberal kuramın fikirlerinin NATO’ya egemen olduğu görülmüștür.

\section{Sosyal İnşacı Güvenlik Yaklaşımı}

Soğuk Savaş'ın bitiminin ana akım uluslararası ilişkiler kuramları üzerine sarsıc1 etkileri olmuştur (Rumelili, 2014: 151). Yeni filizlenen yaklaşımlardan biri de Sosyal İnşacılıktır. Kuramın öne çıkan düşünürü Alexander Wendt'in Social Theory of International Politics adlı kitab1 yazında önemli bir yer tutmaktadır. Sosyal inşacılık disiplinler arası bir yaklaşım olup, psikoloji, siyaset bilimi ve sosyoloji gibi bilim dallarından büyük ölçüde etkilenmiştir (Bozdağlıoğlu, 2007b: 149). Uluslararası 
ilişkilerin sosyal yanına yaptığı vurgu ile bilinen bu yaklaşım, neo-realist kuramda eksiklik olarak gördüğ̈̈ tarihsel ve toplumsal perspektifi temel almaktadır. Yani aktörler yapı ilişkisine dair oluşan durumun karşılıklı olarak sosyal bir biçimde inşa edildiği, dolayısıyla da devletlerin çıkarları veya dış politika tercihleri sadece yapı sayesinde değil aynı zamanda sahip olduğu kimlikle de alakalı olduğu görüşü hâkimdir.

Sosyal inşacı kuram; neo-realizm gibi yapısalcı, sistematik ve devletlerin uluslararası sistemin temel aktörleri olduğunu kabul etmektedirler. Ancak inşacılara göre uluslararası sistemdeki önemli yapılar maddi değil inter-sübjektiftir, devlet kimliği ve çıkarları bu sosyal yapılar tarafından oluşturulmaktadır (Wendt, 1994: 385). Wendt'e göre; "küresel ilişkiler, içinde bulunulan konumun yanında süjelerin içlerindeki iletişim sayesinde oluşturulan biz ve öteki durumlarıyla birlikte bunlar üstüne tesis edilen hal ve beklentilerdir" (Wendt, 1992: 397). Çünkü devletlerin tarihi deneyimleri ve algılamaları, devletlere bir kimlik olgusu yüklemektedir. Sosyal inşacılar kimlik ve çıkar arasındaki ilişkinin ülke davranışlarını yönlendirmede etkili olacağını savunmuşlardır. Uluslararası ilişkilerde barış ortamına yıkıcı etkisi olan 11 Eylül 2001 saldırılarından sonra, Batı medeniyeti değerlerinin (demokrasi, eşitlik ve anayasa gibi) sosyal inşacılık kapsamında özellikle teröre aracılık eden ülkelere aktarılmasının gerekli olduğunu ileri süren düşüncelerin ağırlık kazandığı gözlemlenmiştir. Ortadoğu coğrafyasının, Batılı kimliği temel değerleri doğrultusunda, "Büyük Ortadoğu Projesi" (BOP) adıyla yeniden yapılandırmak istediği anlaşılmaktadır. Terör eylemlerinden sonra El-Kaide düşman ilan edilmiş ve bu çerçevede Orta Asya ve Ortadoğu bir anda terör eylemlerinin kaynağı olarak gösterilmiştir. El-Kaide terör örgütünün konuşlandığ 1 yer olarak işaret ettiği Afganistan'a ABD müdahalesi ilk bakışta meşru bir savunma hareketi biçiminde benimsense de söz konusu güç kullanımı, El-Kaide operasyonu ile kalmamış, Irak'a kadar uzanmıştır. NATO, Ağustos 2003 'te Birleşmiş Milletlerin 20 Aralık 2001 tarih ve1386 sayılı kararıyla Afganistan'da konuşlu Uluslararası Güvenlik Yardımı Gücünün (ISAF) komutasını alarak misyonun stratejik komuta, kontrol ve koordinasyonunu üstlenmiştir. 11 Eylül 2001 sonrası NATO Afganistan misyonu ve benzer diğer müdahaleleri, teröre destek veren ülkelerde Batı değerlerinin yerleştirilmesi için "biz" hissi ve Batılı kimliği altında birleşilmesi, sosyal inşacılık kuramı tarafından desteklendiği ileri sürülebilir. 
Küresel Güvenliğin Dönüşümü; NATO Băglamında Kavramsal, Tarihsel ve Teorik Bir Analiz

Güvenlik Konuları ve Aktörlerinin Değişimi

\section{Soğuk Savaş Dönemi Güvenlik Konuları ve Aktörleri}

İkinci Dünya Savaşı sonrası dönemde sadece Almanya değil Avrupa'nın diğer güçlü devletleri de zayıflamıştır (Hobsbawm, 2008: 1-2). $\mathrm{Bu}$ savaştan, ekonomik ve askeri anlamda en az etkilenen ABD ile beraber Almanya'ya karşı savaşın kaderini belirleyen SSCB, iki "süper güç" olarak ortaya çıkmıştır (Armaoğlu, 1989: 419). Bu iki karşıt ideolojiye sahip devletin mücadelesi olan Soğuk Savaş (Cold War), yarım yüzyıla yakın bir zaman boyunca uluslararası ilişkilere egemen olmuş ve bu ilişkileri büyük oranda belirlemiş bir çatıșma olarak tanımlanmaktadır (McMahon, 2013: 5). $\mathrm{Bu}$ çatışma kendisini açık askeri eylemlerle değil, ekonomik baskı, propaganda ve silahlanma yarışıyla göstermiştir (Keskin, 2004: 536). Süper güçler arasındaki mücadele, artık muharebe meydanlarında değil, nükleer çağın felaket senaryolarıyla bütünleşmiş savaş biçimleriyle yürütülmüştür. Her iki taraf da İkinci Dünya Savaşında geliştirdikleri örtülü, psikolojik ve yer altı savaş yöntemlerini Soğuk Savaş boyunca birbirlerine karşı yöneltmiştir. Bu dönemin aktörleri olarak; iki süper güç ve diğer devletlerin yanında NATO, WP ve BM sayılabilmektedir. Realist paradigma bu dönemde; NATO'nun ve WP'nın kurulmasında, nükleer silah yarışına girilmesinde, ideolojik kamplaşmanın yayılmasında, güvenlikleştirme eylemlerinin sayısının artışında, değişik coğrafyalarda girişilen savaşlara taraf ve destek olunmasinda hatta film sanayinde bile propagandaya dayalı temaların geliştirilmesinde etkili olmuştur. Ancak Küba krizinde, yapılacak en ufak bir hatayla nükleer savaşa girilebileceğinin anlaşılması üzerine başlatılan barışçıl girişimlerin "Yumuşama" sürecine vesile olması realist kuramın yerine kısa bir süre de olsa neo-liberal paradigmanın etkisini arttırmasını beraberinde getirmiştir. Ancak SSCB'nin giriștiği Afganistan müdahalesiyle örneklendirilebilecek saldırgan tutum, realist kurama geri dönüşü beraberinde getirmiş ve Soğuk Savaş sert bir şekilde tekrar hissedilmeye başlamıştır.

\section{Soğuk Savaş Sonrası Güvenlik Konuları ve Aktörleri}

Soğuk Savaş döneminde güvenlik "dar" bir kapsamda ele alınmış ve sadece "askeri güvenlik" kastedilmiştir. Bu tanımlamadan duyulan rahatsızlık ilk önce 1970 ve 80'lerde "ekonomik" ve "çevresel" sorunların gündeme gelmesiyle belirginleşmiş, ardından 1990'larda "kimlik" meseleleri ve "sınır ötesi" suçlar güvenlik tanımlamasını genişletmiştir. 
2000'lerde ise bunlara "enerji güvenliği", "siber güvenlik" ve "sosyal güvenlik" de eklenmiştir. Bu arada "askeri güvenlik" kavramının kapsamı da "uluslararası terörizm" ile genişlemiştir. Böylece güvenliğin daha geniş bir tanımlamasına ulaşılmıştır. Artık askeri ve askeri olmayan öğelerden oluşan geniş tanımlama devletler nezdinde daha çok kabul görmektedir (Aydin, 2005: 4).

Daha önce de bahsedildiği üzere küreselleşme, özellikle ekonomik boyutta yaşanan dönüşümlere sebebiyet vermesinden dolayı, dünyanın güvenlik anlayışını değiştiren unsurlardan en önemlisi olmuştur. Böylece, yeni güvenlik anlayışı olarak askeri boyutla sınırlı olan güvenlik anlayışı ortadan kalkmış, iktisadi, sosyolojik, politik, çevresel, etnik, kültürel konular da modern güvenlik anlayışının tanımlarına eklenmiştir. Tehdit algılamalarına bağlı yeni sorunlar bugün sınırlı sayıda olmayıp, aksine tüm ulusal yapıları ilgilendirmekte ve çözümleri de belirli aktörlerin değil, tüm aktörlerin sorumluluğunda olan konuları kapsamaktadır. Cengiz Okman'ın görüşlerine katılır şekilde, klasik 'ulusal güvenlik' anlayışının yerini yavaştan 'uluslararası güvenlik' kavramına terk ettiği ileri sürülebilir (Okman, 2011: 15). Örneğin bu çerçevede NATO'ya bağlı müttefiklerin silahlı kuvvetleri birkaç kıtada operasyonlar ve misyonlar yürütmektedir.

Soğuk Savaş ve sonrası dönemle birlikte "ulus-devletlerin" yanı sıra "uluslararası örgütlerin", "düşünce kuruluşları ve stratejik merkezlerin", "savunma sanayi ve özel güvenlik şirketlerinin" önemli bir güvenlik aktörü olduğu dikkatleri çekmektedir. Bu dönemde NATO ve BM'nin yanı sıra başta $A B$ ve Şangay İşbirliği Örgütü (ŞIÖ) olmak üzere, birçok güvenlik aktörü uluslararası sistemde rol almaya başlamıştır. Caşın'ın belirttiği üzere tehditler değişse bile devletler ve uluslararası örgütler neo-liberal yaklaşımlar doğrultusunda bireyleri korumayı ve kendi egemenliklerini muhafaza etmeyi bir görev bilmektedir (Şahin, 2016: 272-278).

\section{Kuzey Atlantik Antlaşması Örgütü (NATO) ve Güvenlik Anlayışı}

Ortak savunma/güvenlik örgütü olarak yakın tarihe damgasını vuran NATO, 68 yıl süresince uluslararası sistemdeki gelişmeler karşısında varlığını meşrulaştırabilmiş, bu sebeple de faaliyetlerini bugünlere kadar sürdürebilmiştir. Söz konusu niteliği NATO'yu benzer biçimde tesis edilen diğer uluslararası teşkilatlardan farklı bir konuma taşımıştır (Varlık, 2012: 71). Tabii ki varlık amacının Soğuk Savaş ile birlikte sona erdiği iddia edilerek birçok yönden de eleştiriye maruz kalmıştır (Medcalf, 2005: 3). Ayrıca uluslararası sistemde belli başı başat aktörlerin de kendisini tehdit 
Küresel Güvenliğin Dönüşümü; NATO Bağlamında Kavramsal, Tarihsel ve Teorik Bir Analiz

olarak gördüğü önemli bir güce ve inkâr edilemez kurumsal yapıya erişmiştir. Öyle ki NATO, hâlihazırda dünyanın gelmiş geçmiş en büyük ve önde gelen askeri ittifakı olmuştur. Bütün NATO üyelerinin toplam askeri harcamaları, dünya askeri harcamalarının yüzde 70'ini oluşturmaktadır (Heywood, 2013: 306). 2017 yılı itibariyle 68'inci yaşını dolduran ve 29 üyesi bulunan örgüt; Barış İçin Ortaklık, Akdeniz Diyaloğu ve İstanbul İşbirliği Girişimi ile etki alanını önemli ölçüde genişletmiştir (NATO Member Countries, 2017). Bu çabalar, önümüzdeki yıllarda da NATO’nun uluslararası sistemde aktif rol alacağını göstermektedir.

\section{NATO’nun Kuruluşu ve Soğuk Savaş Dönemi Güvenlik Anlayışı}

Steven W. Hook ve John Spanier, "Büyük güçler güvenlikleriyle ilgili kararları genelde rakiplerine bırakmaz" demektedir (Hook ve Spanier, 2014: 9). Bunu desteklercesine, İkinci Dünya Savaşı sonrası Doğu-Batı Bloğu arasındaki güvensizlik sarmalı ve realist kuramın etkisiyle, Kuzey Atlantik İttifakı'nın kuruluşuna ilişkin Washington Antlaşması, 12 devletin katılımıyla 4 Nisan 1949'da Washington'da imzalanmış ve 24 Ağustos 1949 tarihinde yürürlüğe girmiştir (Hasgüler ve Uludăg, 2007: 307-308).

NATO'nun kuruluş misyonunun; kendisine bağlı üyelerin siyasi ve askeri özgürlüklerini, ittifak anlaşmasına ve BM Şartı'na uygun bir şekilde demokrasi, insan hakları, hukukun üstünlüğü temelinde sağlamak olduğu belirlenmiştir. Tesis edilen transatlantik münasebetlerle Kuzey Amerika ve Avrupa savunmasının bir tutulacağının altı çizilmiş ve ortak çıkarların savunulmasında üye devletler arasındaki iş birliğinin ve Avro-Atlantik güvenliğinin bölünmezliği bağlamında oluştuğu ifade edilmiştir (The Treaty and its fundamental values and principles, 2017). NATO'nun meşruiyetini; BM Antlaşmasının bölgesel düzenlemelere ilişkin 52'nci ve 54'üncü maddelerine dayandırmaktadır. Ayrıca 51'inci madde de; üye bir devlete saldırı söz konusu ise güvenlik konseyi gerekli tedbirleri alıncaya kadar bireysel ya da ortak güç kullanımına başvurabileceği belirtilmektedir (Charter of The United Nations, 1945). Kuzey Atlantik İttifak1, kamuoyu tartışmaları ve parlamenter süreçler sonunda ülkelerin antlaşmaya özgür iradeleriyle katılmaları temeli üzerinde oluşmuştur. Bu tarihten itibaren NATO, önce Avrupa daha sonra da Avrupa'nın dışına da çıkmak şeklinde güvenlik ve savunma sisteminde temel ve merkezi bir rol oynamaya başlamıştır (Tangör, 2009: 29).

Soğuk Savaş döneminde NATO, yayımlanmış dört temel konsepti dâhilinde faaliyetlerini icra etmiştir. Bunlar; "Tecavüzü Caydırma", "Entegre Askeri Kuvvetin Oluşturulması", "Topyekûn Mukabele" ve 
"Esnek Mukabele" olarak ortaya konmuştur. 1953’te Kruşçev, 1960'l yılların başında Charles De Gaulle, 1962'de Kennedy, 1967'de Willy Brandt, tarafindan çeşitli vesilelerle konu edilen "Yumuşama" gayretleri, 1969-1978 yılları arasında yaşama geçirilmiştir. Harmel Raporu'nun NATO'da onaylanmasına müteakip, 1969'da dönemin ABD başkanı Richard Nixon ve dışişleri bakanı Henry Kissinger'in yaklaşımlarıyla "Yumuşama" stratejisine geçilmiştir. Doğu Bloğu tarafindan 1969'da "Budapeşte Önerisi" başlı̆̆ıla kamuoyuna ilan edilen ve Avrupa'da iki blok arasında gerilimin düşürülmesine yönelik çabalar, önceleri itibar görmediyse de yaklaşık altı yıl sonra kaleme alınan Helsinki Nihai Belgesi'nin temelini teşkil etmiştir.

Yumuşama döneminde gerçekleşen "4 NATO zirvesinde"; dayanışma, istişare ve oydaşma aygıtlarının başarıyla kullandığı, savunma harcamalarında olduğu gibi savunma politikalarında da tam bir beraberlik içinde karar alındığ 1 ve hareket edildiği gözlemlenmiştir (Ottawa Summit, 1974; Brussels Summit, 1975; Londra Summit, 1977; Washington Summit 1978). Söz konusu zirvelerde barış için iş birliğini gerekli gören liberal kuramın etkisi açı olarak hissedilmiştir.

İki kutup arasındaki ideolojik bunalımın Avrupa dışında bölgesel çatışmalara dönüştügü 1979 ile 1985 yılları arasındaki 6 yıllık süre, bazı bilim insanlarınca “İkinci Soğuk Savaş" şeklinde tanımlanmıştır. SSCB'nin Afganistan'ı işgali; Polonya'daki özgürlük yanlısı direnişlerin sert bir şekilde bastırılması; Afrika, Güneydoğu Asya, Güney Amerika'da Moskova eğilimli hükümetlerin iktidarı devralması; SSCB'nin Akdeniz'deki askeri kimliğini kuvvetlendirmesi ve Orta Doğu'daki etkisini artırması; Batı dünyasının SSCB tehlikesini iktisadi iş birliğiyle "Yumuşatılması" politikasını sonlandırmıştır. Yumuşama yılları sonrasında gerçekleşen "2 NATO zirvesinde" realist kuramın fikirleri tekrar egemen olmuştur (Bonn Summit, 1982; Brussells Summit, 1985).

\section{Soğuk Savaş Sonrası NATO Güvenlik Anlayışı}

Soğuk Savaş sonrasında NATO için güvenlik kavramı da değiş̧miştir. 1990'lara kadar etkin olan SSCB ile müttefiklerine karşı geliştirilen savunma anlayışı yerini göreceli daha küçük çaplı bölgesel tehditlere bırakmıştır. NATO askeri kuvvetlerinin ana görevleri de savunmadan ziyade barışı koruma ve insani yardım amaçlı müdahaleler olmuştur (Gürsoy, 2012: 5). Küreselleşmeyle birlikte çeşitlenen risk ve tehdit tanımlamaları yanında çevre sorunları, iklim değişikliği, siber güvenlik, uluslararası göç, bulaşıcı hastalıklar gibi güvenlik özneleri de 
NATO’nun gündemine girmiştir. Devlet merkezli askeri güvenlik, yerini birden daha fazla uluslararası ilişkiler aktörünün devreye girdiği ve insanı ilgilendiren hemen her unsuru kapsayan ortak bir güvenlik anlayışına bırakmıştır. Çünkü SSCB tehdidinin ortadan kalkmasıyla birlikte misyonu da tamamlayan NATO, yeni dönemde yeni güvenlik öznelerinin bulunmasıyla birlikte varlığını meşrulaştırabilmiştir.

Örgütte alınan bir diğer önemli karar da genişleme olmuştur (Tepe, 2002: 47). Genişleme ile amaçlananın, Orta ve Doğu Avrupa ülkelerinin NATO'ya alınmasıyla birlikte Avrupa'da mevcut istikrarsızlık kaynaklarının ortadan kaldırılması ve NATO'nun yirmi birinci yüzyılda da dünyanın güvenlik ihtiyacına cevap verebilmesi olduğu söylenebilir.

Soğuk Savaş sonrası dönemde NATO; BİO anlaşmaları çerçevesinde, WP ülkeleriyle de özel bir ilişkiler ağı oluşturmaya başlamıştır (Rupp, 2002: 12). Tarık Oğuzlu'ya göre, "Barış İçin Ortaklık (BİO-Partnership for Peace, PFP) girişimi bağlamında NATO'yu harekete geçiren en önemli motivasyonlardan bir tanesi Soğuk Savaş'ın bitiminden sonra NATO'ya alternatif olarak sunulan güvenlik yapılanmalarının cazibesini sınırlı tutmaktır" (Oğuzlu, 2013: 11). NATO’nun; "BİO, Akdeniz Diyaloğu ve İstanbul İşbirliği Girişimi” ortaklarının sayısı 32; kendisine bağlı üyelerin de 29 olduğu düşünüldüğünde NATO'nun 61 devlet ile ortak bir güvenlik örgütüne dönüştügü rahatlıkla söylenebilir. Öyle ki bu ülkeler Soğuk Savaş sonrası dönemde kutuplaşmadan ziyade ortak akıl ile yönetilen bir dünya barışını tesis etmek için çalışmaktadırlar. $\mathrm{Bu}$ tespit, yine NATO'nun bu şekilde işbirliklerine girmesinde neo-liberal politikaların etkisini ispatlamaktadır. Görüldüğü üzere neo-liberal kuram, NATO'nun barışı, işbirliğini ve istikrarı sağladığı gerekçesiyle örgütün alan dışı müdahalelerde bulunmasının, genişlemesinin ve insani müdahalelerde bulunmasının fikirsel alt yapısını oluşturmaktadır.

NATO'nun politik ve askeri bir değişim hareketi başlatarak genişleme stratejisini ortaya koymasında, bölgesel ve uluslararası alanlarda meydana gelen ucu bucağ farklılaşan "güvenlik" yaklaşımı etkili olmuştur. Güvenlik anlayışının daha geniş bir bakış doğrultusunda ele alınmasıyla, NATO'nun etkinlik coğrafyası ve sınırlarını genişletmesi politikası benimsenmiştir (Purtaş, 2005: 9).

1991 y1lındaki Roma Zirvesi’yle Atlantik ittifakının dönüşüm süreci hız kazanmış ve 1999'da gerçekleştirilen Washington Konferansı sırasında da "kolektif savunma" yerine "kolektif güvenlik" anlayışına geçilmesi kabul edilmiştir. Soğuk Savaş döneminin başat kuramı realizmin, Soğuk Savaş sonrası dönemde yerini neo-liberalizme bıraktığı gözlemlenmektedir. Bu 
bağlamda neo-liberalizmle birlikte geniş katılımlı bir işbirliği ön plana çıkmaya başlamıştır. NATO'nun bu yönde attığı ilk önemli adım, Haziran 1992'de Oslo'daki dışişleri bakanları toplantısında, Avrupa'da ortaya çıkacak bunalımlarda NATO'nun barışı koruma işlevini üstlenmeyi kabul etmesi olmuştur. Burada, AGIK'in NATO'dan barışı korumak amacıyla yardım isteyebilmesi kabul edilmiştir (www.nato.int, 2017). Ocak 1994 tarihli Brüksel zirvesinde; $\mathrm{BM}, \mathrm{AGIK}, \mathrm{AB}$ gibi uluslararası ve bölgesel kuruluşların önemini koruduklarını, ancak güvenlik örgütü olarak NATO'nun merkezi rol oynaması gerektiği ifade edilmiştir. Bu çerçevede NATO öncelikle, barışı koruma faaliyetlerine katılabilmesini kolaylaştıracak kurumsal bir yapılanmaya gitmiştir. $\mathrm{Bu}$ amaçla Ocak 1994’te Birleşik Ortak Görev Kuvveti (Joint Combined Task Force-JCTF) tesis edilmesine karar verilmiştir (Declaration of the Heads of State and Government, 2000). Bununla iki amaç hedeflenmiştir: İlk olarak NATO, üyesi olmayan ülkelerle ortak barışı koruma operasyonları düzenlemenin yollarını geliştirmeye çalışmıştır. Aralık 1994'de ise NATO ve AB, stratejik çıkarları paylaşmak ve aynı zorluklarla yüzleşmek için ortak çıkar konularında iş birliği yapmak, kriz yönetimi, yetenek geliştirme ve siyasi istişarelerde yan yana çalışmak konularında anlaşmışlardır (www.nato.int, 2017). NATO'nun fikirsel dönüşümünde Batı'nın yeni savaş tanımlaması da etkili olmuştur. Devletlerin devletlere değil de örgütlerin başarısız devletlerin egemenlik sahalarına müdahalesinin doğru olacağını savunan yeni tanım, NATO'ya askeri müdahalelerinde, barışı destekleme görevlerinde ve insani yardımlarında meşru bir fikirsel zemin sağlamıştır. Öyle ki Kuzey Atlantik'i Sovyet tehdidine karşı korumak için tesis edilen örgüt, artık dünya barışına katkı sağlamak için neo-liberal düzlemde oyuna dahil edilmiştir. İkinci olarak, Almanya ve Fransa'nın temsil ettiği Avrupa güvenlik sisteminin geliştirilmesi yaklaşımıyla $A B D$ ve İngiltere'nin temsil ettiği NATO ağırlıklı güvenlik yaklaşımı arasında bir uzlaşma sağlanması hedeflenmiştir.

Soğuk Savaş sonrası dönemde "16 NATO zirvesinin" icra edildiği gözlemlenmektedir. $\mathrm{Bu}$ zirvelerde alınan kararlar doğrultusunda güvenlikleștirilen tehdit ve riskler, NATO'nun varlık sebebiyetini oluşturmuştur (NATO Summit Meetings, 2017). Zirveler ve zirve sonuç bildirileri, NATO'nun güvenlik anlayışının dönüştüğünü gösteren temel metinler olmuşlardır. Bu temel metinler tabi ki de Soğuk Savaş sonrasında değişen güvenlik anlayışı çerçevesinde kaleme alınmıştır. 11 Eylül 2001 terör saldırıları öncesinde gerçekleştirilen zirvelerde neo-liberal kuramın, iş birliğini güçlendirdiği ve barışı koruduğunu ileri süren görüşleri etkisini göstermiştir. Bu kapsamda NATO; Bosna Hersek, Kosova, Makedonya, 
Afganistan ve Libya'da kriz yönetimi ve barışı destekleme operasyonları; Akdeniz'de terörle mücadele operasyonu; Aden Körfezi'nde korsanlarla mücadele operasyonu; Irak’ta eğitim destek misyonu ve Afrika Birliği için bir destek misyonu icra etmiştir.

Müdahaleler, kriz yönetimi ve barışı destekleme operasyonlarına bakıldığında ilk yapılan operasyonlarda "insani ilkeler" ön planda tutulmuş ve neo-liberal kuramın fikirlerinin NATO'ya egemen olduğu görülmüştür. Ancak 11 Eylül 2001 sonrası yapılan müdahalelere gerekçe oluşturması açısından realist kuramın güç kullanımı düşüncesinden ziyade sosyal inşacılığın kimlik kavramı kullanılmış, teröre karşı olanlar ve teröre destek verenler yani "biz" ve "ötekiler" diye bir ayrım yapılmış, neo-liberallerin barış söylemlerine ek olarak sosyal inşacı kuram terörizmi destekleyen ülkelere karşı birleştirici olarak kullanılmıştır.

19-20 Kasım Lizbon Zirvesi'nin hemen sonrasında Aralık 2010'da yayınlanan Allied Joint Doctrine AJP-01-D (Müttefik Birleşik Doktrini), NATO'nun askeri alandaki dönüşümünün bir aşaması olarak kabul edilebilmektedir. Konvansiyonel tehdit ve saldırıya karşı hazırlanmış olan eski askeri anlayışın yerine, 5'inci madde dışındaki faaliyetlere uygun şekilde geliştirilmeye çalışılmıştır (Karaosmanoğlu, 2012: 41). Bu belgede öne çıkanlar beş başlık altında toplanmıştır (Allied Joint Doctrine (AJP-01D), 2010): İlkin NATO, silahlı çatışmadan insani müdahaleye kadar her çeşit askeri operasyonu potansiyeli itibariyle üstlenmektedir. İkinci olarak NATO, klasik sorumluluk alanı içindeki operasyonlarla o alanın dışındaki operasyonlar arasında temelde bir fark bulunmadığını bildirmektedir. Üçüncü olarak NATO için bütünleşmiş güç önem arz etmektedir. Bu güç diplomasi, ekonomi ve askeri unsurlardan meydana gelmekte ve ittifakın istihbarat yeteneğini kullanmaktadır. Dördüncü olarak askeri güç NATO bünyesinde stratejik, operatif ve taktik seviyede diğer unsurlarla birlikte iç içe ve koordineli bir şekilde kullanılmaktadır. NATO’nun askeri dönüşümü teknolojik ve stratejik boyutu içermektedir. Son olarak NATO'nun operasyonları çokuluslu olduklarından, üye orduların ileri düzeyde işbirliği ve koordinasyonu, komuta birliğiyle sağlanmaktadır. Üyeler arasında belli bir olayda mutabakat oluşursa bu güç neo-liberal kuramın işbirliği ve sosyal inşacılık kuramının "biz" kavramıyla bütünleşmiş olarak harekete geçmektedir.

NATO'nun önümüzdeki on yıllarda eleştirel kuramın da konuları çerçevesinde yeni dönüşümler geçireceği söylenebilir. Bu bağlamda insani müdahale kavramlarını da içermesi bakımından eleştirel kuramdan faydalanabilir. Özellikle 2014 Galler zirvesinde kadınların ve çocukların durumlarının iyileştirilmesi konulu bir başlık açması, ilerleyen zirvelerde 
eleştirel kuramın fikirlerinin de etkili olup NATO'nun dönüşümüne etki edeceği ileri sürülebilir.

Enver Bozkurt'un da dediği üzere, "savunma amaçlı bir örgüte mutlaka ihtiyaç bulunmaktadır" ve bu yüzden NATO'nun varlığ tartışılmamalıdır. Küresel veya bölgesel seviyede ortak güvenliğin teminatı olabilecek bir uluslararası veya uluslar-üstü örgüt, dünyanın geleceği adına önem arz etmektedir (Bozkurt, 2007, 187). NATO dönüşürken ütopik davranmamalı, dünya barışını tehdit edebilecek bir potansiyele sahip ülkelere karşı kurumsal hafızasına başvurmalı, gerektiğinde konvansiyonel güce başvurmayı bir seçenek olarak elde bulundurmalıdır. Nitekim 2014'te yaşanan Ukrayna krizi ve sonrasında Rusya'nın Kırım'ı ilhakı, NATO'ya ne kadar büyük şiddette ihtiyaç duyulduğunu kanıtlamıştır.

\section{Sonuç}

Soğuk Savaş döneminde temel olan devletin güvenliğidir. Devletin güvenliği savunma ile eş değerde tutulmuş, bu bağlamda güç kullanımı meşru sayılmıştır. Devletler askeri güce ulaşmak adına silahlanmışlar ve iki blok etrafındaki kolektif savunma örgütlerine üye olmuşlardır. Bu durumu en iyi açıklayan uluslararası ilişkiler kuramı realist paradigma olagelmiştir. Soğuk Savaş'ın yerini yumuşama dönemine bıraktığı yıllarda liberal kuramlar etkinlik kazanmış, karşılıklı işbirliğiyle sorunların çözülebileceği inancını empoze etmişlerdir. Ancak 1979'da Afganistan'a SSCB müdahalesi; 1980'de başlayan İran-Irak Savaşı ve ABD'de Reagan hükümetinin Yıldız Savaşları projesini öne sürmesiyle birlikte Soğuk Savaş'a geri dönülmüştür (www.coldwar.org, 2015). Böylece realist paradigmanın temel kuralları tekrar işlerlik kazanmıştır.

Soğuk Savaş'ın sona ermesi ve Komünizm tehlikesinin ortadan kalkmasıyla, realist paradigmaya göre NATO da geçerliliğini yitirmiştir. Ancak başta İngiltere olmak üzere üyeler ve Avrupa'daki neo-liberal görüssler, NATO'nun güvenlik iş birliğini kolaylaştırdığını ve oluşacak yeni tehditlere karşı NATO’nun mevcudiyetini koruması gerektiğini ortaya koymuşlardır. Nitekim bu görüşler kısa zamanda etkinlik kazanmış ve NATO'nun 1989 yllındaki zirvelerinden sonra neo-liberal paradigmanın etkisinde dönüşüm geçirerek yeni güvenlik konularına göre kendisini revize ettiği gözlemlenmiştir. $\mathrm{Bu}$ bağlamda, zirvelerde yeni tehditler ortaya konmuş, NATO da bu yeni tehditler 1şı̆̆ında alan dışına çıkarak yeni güvenlik konuları çerçevesinde konseptler geliştirmiştir.

Soğuk Savaş sonrası dönemde sınırların korunması esasına dayalı askeri savunma anlayışı yerini, milletin bekasının sınır ötesinde ya da daha 
Küresel Güvenliğin Dönüşümü; NATO Bağlamında Kavramsal, Tarihsel ve Teorik

Bir Analiz.

uzaktan sağlanmasını merkezine yerleştiren 'stratejik bir güvenlik' yaklaşımına terk etmiştir. Böylece 'stratejik güvenlik' tanımını, olası risk ve tehlikeleri öncelikle tehdit biçimini almadan tespit edip bunları ülke sınırlarına gelmeden engellemek, eğer mümkün değilse başka bir yere yönlendirmek veya daha oluşmadan kaynağında bitirmek maksadıyla hazırlanan ve tatbik edilen önlemler projesi şeklinde açıklamak mümkündür (Kuloğlu, 2009: 52-53). Bir nevi hatayı kaynağında önlemeye benzetilecek bu yaklaşım, böylece yıkıcı savaşlara, yıpratıcı terör saldırılarına maruz kalmadan hamlelerin yapılmasını içermektedir. Boyutları genişleyip konuları çeşitlenen küresel güvenliğin önemli bir aktörü olan NATO, böylesine dönüşen bir yapıyı kontrol edebilmek için alan dışına çıkarak çeşitli kritik coğrafyalarda işbirlikleri geliştirmiş, müdahalelerde bulunmuş ve "insani müdahale" gerekçesini bir meşruiyet unsuru olarak ortaya koymuştur. İttifak, kitle imha silahlarının (KİS) ve balistik füze teknolojisinin yayılması, terörizmle mücadele, siber güvenliğin arttırılması ve enerji güvenliğinin güçlendirilmesi dâhil çeşitli güvenlik sorunlarıyla karşı karşıya kalmaktadır. Bu sorunlarla başa çıkabilmek için NATO, hem askeri yeteneklerini modernleştirmekte hem de misyonlarını yürütebilmek için yeterli kaynaklara (finansal, askeri ve insan) sahip olmak için planlamalar yapmaktadir.

11 Eylül 2001 sonrası dönemde, neo-liberal paradigmanın yanında sosyal inşacılık da güç kazanmıştır. NATO; "biz hissi" yaratan Batılı kimliğini ve değerlerini zirvelerinde, konseptlerinde ve misyonlarında sıklıkla kullanmıştır. Sonuç itibariyle; Soğuk Savaş sonrası dönemde değişen ve çeşitlenen güvenlik konuları neo-liberal fikirler ve kısmen de olsa sosyal inşacı kuram eşliğinde dönüşüm yaşamış; çatışmacı zihniyetten işbirlikçi bir rol modele doğru evirilerek "ulus-devletlerin" yanı sıra "uluslararası örgütlerin", "düşünce kuruluşları ve stratejik merkezlerin", "savunma sanayi ve özel güvenlik şirketlerinin" önemli bir güvenlik aktörü olduğu tüm Dünya'yı kapsayan bir yapıya kavuşmuştur.

\section{Extended Summary}

\section{The Transformation of Global Security; A Conceptual, Historical and Theoretical Analysis in the Context of NATO}

Security which is one of the most important topics of international relations can simply be defined as the preservation of the acquired values, and to achieve this state of security, states, international organizations and 
other agents go through a both conflicting and cooperative process. NATO which was founded in accordance with the realist theory due to the insecurity sourced by the competition in the western bloc was appraised as a strong proponent of world peace because it survived the Post-Cold War era and defended universal values. In the framework of neo-liberal theory of the post 1990 London Summit era, NATO stood strong even after Cold War because of its ability to intervene in crisis, and strong cooperation with EU and UN for peace. After the $9 / 11$ terrorist attack, along with the neo-liberal theory, the social constructivism`s thesis that NATO facilitates cooperation by creating a spirit of unity has become of the basis of NATO`s existence.

After the end of the Cold War, the topics of security diversified, and in order to justify its existence and counter new threats, NATO had to adapt to this chance in the understanding of security. This paper supports the thesis that "in this new era when the realist understanding of security which has been linked to the state centered military power has changed, the subjects of the security politics have diversified, the risks and threats have increased, aside from the nation states, international organizations are active, NATO evolves because of facilitating cooperation for security within the framework of neo-liberal and social constructivist theory." While preparing the thesis, majorly NATO summits and interventions have been studied.

By the 1991 Rome Summit the process of change of the North Atlantic Alliance has sped up, and during the 1999 Washington Conference, it was decided to adapt the collective security concept instead of the collective defense concept and to out of area missions. However, the events after 1999 and the emerging threats forced the changes in NATO again. In the context of the modern understanding of security, NATO plans to locate and clear away potential risk and dangers with being threatened and approaching their borders.

Along with the change of the concept of security, the extent and scope of security also changed. In fact, security was also globalized by adapting to the international system. The extent of security evolved from the definition of security of nation state to the regional and international understanding of security which is also called global security. The topics of security changed; In this sense, many topics have appeared such as international terrorism, regional disputes, cyber security, contagious diseases, international immigration, environmental problems and climate change.

The actors also diversified: Next to the states, not only NATO and UN, but also EU, Shanghai Cooperative Organization (SCO), other non- 
Küresel Güvenliğin Dönüşümü; NATO Bağlamında Kavramsal, Tarihsel ve Teorik Bir Analiz.

governmental organizations, defense industry, private security companies and think tanks started playing important roles in the system. With concern regarding its future existence, NATO began to spend effort transforming in the framework of the new topics of security and actor. It is possible to see the indications of this change in the summits that took place after the Cold War.

It is necessary to denote that instead of the understanding of security, which prioritizes the classical military aspect of power and bases on the nation with the principles of the nuclear balance during the Cold War, today a more inclusive and multidimensional understanding of security is pervasive. In the past, an individual as a member of the nation was a topic of security and security mostly meant the protection that the states provided to their citizens. As for today, "the individuals" is a topic of security. Besides, the humanitarian intervention ground has been an element of justification for the interventions done by NATO.

As a part of the changing understanding of security, NATO which is a significant actor of extending and diversifying concept of global security had to establish collaborations in critical locations by stepping out of its area of responsibility. In order to achieve the goals mentioned, the organization with its 29 members has expanded its power by Partnership for Peace, Mediterranean Dialogue and Istanbul Cooperation Initiative. It can be argued that the reason for it to expand its power lies not in the realist theory but in the neo-liberal theory which defends that NATO can be effective at facilitating world peace. After the Cold War, NATO carried out a support mission to the crisis management and peace keeping operations in Bosnia and Herzegovina, Kosovo, Macedonia, Afghanistan and Libya, counterterrorist operation in Mediterranean, counter-piracy operations in Gulf of Aden, education support in Iraq and African Union.

In conclusion; this paper studies the case of security conceptually and theoretically and shows the changes in the understanding of security by determining the topics of security and actors. Furthermore, it evaluates the significance of NATO in light of the topics mentioned, reasons for it to still exist, and its change in light of the principles set forth after the summits in frame of politics of global security. This study is significant in order to determine the elements of change in the global security system, make connections between the old and new eras and to question NATO's legitimacy in the changing understanding of security.

It was seen that in light of partially social constructivism and majorly neo-liberalism NATO did not cease to exist in the Post-Cold War era when the threat of the Eastern Bloc disappeared and was supported by the 
members. Today, its main ideal is to develop its own policies against emerging threats and risks and continue its transformation in the context of the changing understanding of security.

\section{Kaynakça}

\section{Kitaplar}

Arı T. (2006). Uluslararası İlişkiler Teorileri. Alfa Yayınları, İstanbul.

Armaoğlu F. (1989). 20. Yüzyıl Siyasi Tarihi. Türkiye İş Bankası Kültür Yayınlar1, Ankara.

Birdişli F. (2014). Teori ve Pratikte Uluslararası Güvenlik: Kavram-TeoriUygulama. Seçkin Yayınevi, Ankara.

Gönlübol M. (2000). Uluslararası Politika: Illkeler-KavramlarKurumlar. 5.Bask1. Siyasal Kitabevi, Ankara.

Griffiths M., O’Callaghan T. ve Roach S.C. (2013). Uluslararası Illişkilerde Temel Kavramlar. (çev. CESRAN). 2.Baskı. Nobel Yayınları, Ankara.

Gürsoy Y. (2012). Türkiye'de Sivil-Asker İlişkilerinin Dönüşümü, İstanbul Bilgi Üniversitesi Yayınları, İstanbul.

Hasgüler M. ve Uludağ M.B. (2007). Devletlerarası ve Hükümetler Dışı Uluslararası Örgütler. Alfa Yayınları, İstanbul.

Heywood A. (2013). Küresel Siyaset. (çev. N. Uslu ve H. Özdemir). Adres Yayınları, Ankara.

Hobsbawm E. (2006). Milletler ve Milliyetçilik: Program, Mit, Gerçeklik. 3.Baskı. (çev. O. Akınhay). Ayrıntı Yayınları, İstanbul.

Hook S.W. ve Spanier, J. (2014). Amerikan Dış Politikası: İkinci Dünya Savaşı'ndan Günümüze. (çev. Ö. Zihnioğlu Tanırlı). İnkılâp Kitabevi Yayınları, İstanbul.

McMahon R.J. (2013). Soğuk Savaş. (çev. S. Gül). Dost Kitabevi Yayınları, Ankara.

Medcalf J. (2005). NATO: Beginners Guides. Oneworld Publications, Oxford.

Oğuzlu T. (2013). NATO Ortaklıkları ve Türkiye: Barış Iç̧in Ortaklık, Akdeniz Diyalogu, İstanbul İşbirliği Girişimi, İstanbul Bilgi Üniversitesi Yayınları, İstanbul.

Rupp M. (2002). Avrupa Birliği'nin Ortak Dışişleri ve Güvenlik Politikası ve Türkiye'nin Uyumu. İktisadi Kalkınma Vakfı Yayınları, İstanbul.

Sönmezoğlu F. (2009). Uluslararası İlişkilere Giriş. 3.Baskı. Der Yayınları, İstanbul. 
Küresel Güvenliğin Dönüşümü; NATO Bağlamında Kavramsal, Tarihsel ve Teorik Bir Analiz

Şahin G. (2016). Küresel Güvenlik ve NATO; Teori, Aktör, Tehdit, Risk. Detay Yayıncilık, Ankara.

Tangör B. (2009). Avrupa Birliği Güvenlik ve Savunma Politikası'nın Gelişimi. Seçkin Yayıncılık, Ankara.

\section{Makaleler}

Ağcan M.A. (2014). "Sosyal Bilimler Felsefesi ve Uluslararası İlişkiler Teorisi”. Küresel Siyasete Giriş: Uluslararası İlişkilerde Kavramlar, Teoriler, Süreçler. E. Balta (der.). İletişim Yayınları, İstanbul.

Aydın M. (2005) "Küreselleşme Karşısında Ulus Devlet-Ulusal Ekonomi ve Güvenlik". Panorama Dergisi. Sayı:12.

Aydın M. (2004) 'Uluslararası İlişkilerin 'Gerçekçi' Teorisi: Kökeni, Kapsamı, Kritiği’”. Uluslararası İlişkiler Dergisi, Cilt: 1. Sayı: 1.

Bilgin P. (2003). "Türkiye-AB İlişkilerinde Güvenlik Kültürünün Rolü”. Soğuk Savaş Sonrasında Avrupa ve Türkiye. C. Karadeli (der.). Ayraç Yayınevi, Ankara.

Bozdağlıŏlu Y. (2007a). "Realizm”. Uluslararası İlişkiler: Giriş, Kavram ve Teoriler. H. Çakmak (der.). Platin Yayınları, Ankara.

Bozdağlığlu Y. (2007b). "Yapılandırmacı Yaklaşım (Konstrüktivizm)". Uluslararası Illişkiler: Giriş, Kavram ve Teoriler. H. Çakmak (der.). Platin Yayınları, Ankara.

Brauch H.G. (2012). "Güvenliğin Yeniden Kavramsallaştırılması: Barış, Güvenlik, Kalkınma ve Çevre Kavramsal Dörtlüsü”. Uluslararası Ilişkilerde Çatışmadan Güvenliğe. M. Aydın (der.) vd. İstanbul, Bilgi Üniversitesi Yayınları.

Brauch H.G. (2008) "Güvenliğin Yeniden Kavramsallaştırılması: Barış, Güvenlik, Kalkınma ve Çevre Kavramsal Dörtlüsü”. Uluslararası Ilişskiler Dergisi. Cilt:5. Sayı:18.

Hobsbawm E. (2008) “20.Yüzyılda Savaş ve Barış”. Küreselleşme, Demokrasi ve Terörizm. Agora Yayıncilık, İstanbul.

İzci R. (1998) "Uluslararası Güvenlik ve Çevre". Uluslararası Politikada Yeni Alanlar-Bakışlar. F. Sönmezoğlu (der.). Der Yayınları, İstanbul.

Karaosmanoğlu A.L. (2012). NATO’nun Dönüşümü, İstanbul Bilgi Üniversitesi Yayınları, İstanbul.

Karyotis G. (2007). "Securitization of Greek Terrorism and Arrest of the Revolutionary Organization November 17'. Cooperation and Conflict. Vol:42. 
Kelstrup M. (2004) "Globalisation and Societal Insecurity: The Securitisation of Terrorism and Competing Strategies for Global Governance" Contemporary Security Analysis and Copenhagen Peace Research, S. Guzzini and D. Jung (ed.). Routledge, London.

Keohane R.O. and Nye J.S. (2000). "Globalization: What's New? What's Not? (And So What?)". Foreign Policy. No:118.

Keohane R.O. ve Nye J.S. (2007) "Karmaşık Karşılıklı Bağımlılık", Uluslararası İlişkiler ve Siyaset Teorisi Üzerine Bir Değerlendirme. (çev. Z. Çitak). H. Williams, M. Wright ve T. Evans (der.). Phoenix Yayınları, Ankara.

Keskin F. (2004). "Soğuk Savaş Kavramı ve Kronolojisi”. Türk Dış Politikası, Kurtuluş Savaşından Bugüne Olgular, Belgeler, Yorumlar. Cilt II. 7.Baskı. B. Oran(der.). İletişim Yayınları, İstanbul.

Kuloğlu A. (2009) “Türkiye'nin Güvenlik Algılamaları ve ABD Politikalarının Güvenliğimize Etkileri”. Stratejik Araştırmalar Dergisi. Cilt:1. Say1:3.

Moravcsik A. (1993) "Preferences and Power in the European Community: A Liberal Intergovernmentalist Approach". Journal of Common Market Studies. Vol:31. No:4.

Okman C. (2011). "21.Yüzyıl Güç Merkezleri ve Stratejik Yaklaşımlar". Dünya Jeopolitiğinde Türkiye. H. Çomak (der.). Hiperlink Yayınları, İstanbul.

Purtaş F. (2005) “Soğuk Savaş Sonrası NATO'nun Dönüşümü ve Genişlemesi Çerçevesinde Türk Amerikan Askeri İlişkileri". Güvenlik Stratejileri Dergisi. Sayı:2. Harp Akademileri Basım Evi, İstanbul.

Rumelili B. (2014) “İnşac1lı/Konstrüktivizm”. Küresel Siyasete Giriş: Uluslararası İlişkilerde Kavramlar, Teoriler, Süreçler, E. Balta (der.). İletişim Yayınları, İstanbul.

Tepe E.B. (2002), "Prag Zirvesi: Genişlemeye Devam mı?”. Stratejik Analiz Dergisi. Say1:31.

Varlık A.B. (2012). "Askerî ve Ekonomik Veriler Işı̆̆̆ında NATO'nun Esnekliği”. Savunma Bilimleri Dergisi. Cilt:11. Sayı:2.

Waever O. (2008). “Toplumsal Güvenliğin Değişen Gündemi”. Uluslararası İlişkiler Dergisi. Cilt:5. Sayı:18.

Wendt A. (1992). "Anarchy is what states make of it: the social construction of power politics". International Organization. Vol:46. No:2.

Wendt A. (1994). "Collective Identity Formation and the International State". American Political Science Review. Cilt:88. No:2. 
Küresel Güvenliğin Dönüşümü; NATO Bağlamında Kavramsal, Tarihsel ve Teorik Bir Analiz

Wolfers A. (1952). "National Security as an Ambiguous Symbol". Political Science Quarterly. Vol: 67. No: 4.

\section{Yazarı belli olmayan web sitesi makalesi}

Allied Joint Doctrine (AJP-01-D) 2010. https://www.gov.uk/government/ uploads/system/uploads/attachment_data/file/33694/AJP01D.pdf, (Erişim tarihi: 10.04.2014).

Bonn Summit 1982. http://www.nato.int/docu/comm/49-95/c820610a.htm, (Erişim tarihi: 11.03.2015).

Brussels Summit 1975. http://www.nato.int/docu/comm/49-95/c750529a. htm, (Erişim tarihi: 11.03.2015).

Brussells Summit 1985. http://www.nato.int/docu/comm/49-95/c851213a. htm, (Erişim tarihi: 11.03.2015).

Charter of The United Nations. San Francisco 1945. https://treaties.un.org/ doc/publication/ctc/uncharter.pdf, (Erişim tarihi: 12 Mart 2014).

Declaration of the Heads of State and Government, NATO Resmi Sayfas1, 31 Ekim 2000. http://www.nato.int/docu/ comm/49-95/c940111a. htm, (Erişim tarihi: 07 Haziran 2015).

Londra Summit 1977. http://www.nato.int/docu/comm/1999/9904-wsh/preseng/13role.pdf, (Erişim tarihi: 11.03.2015).

NATO Member Countries. http://www.nato.int/cps/en/natohq/ nato_countries.htm, (Erişim tarihi: 16.09.2017).

NATO Summit Meetings. http://www.nato.int/cps/en/ natohq/topics_50115.htm, (Erişim tarihi: 20.09.2017).

Ottawa Summit $1974 . \quad$ http://www.nato.int/docu/comm/4995/c740618a.htm, (Erişim tarihi: 11.03.2015).

Washington Summit 1978. http://www.nato.int/docu/comm/4995/c780530a.htm, (Erişim tarihi: 11.03.2015).

The Treaty and its fundamental values and principles. http://www.nato.int/cps/en/natolive/topics_67656.htm, (Erişim tarihi: 07 Ekim 2017).

http://www.coldwar.org/articles/80s/SDI-StarWars.asp, (Erişim tarihi: 09.02.2015).

http://www.nato.int/cps/en/natohq/official_texts_23984.htm?selectedLocale =en, (Erişim tarihi: 20.09.2017).

http://www.nato.int/cps/en/natohq/topics_49217.htm?selectedLocale=en, (Erişim tarihi: 20.09.2017). 